\title{
Priming effect of glucagon-like peptide-1 (7-36) amide, glucose-dependent insulinotropic polypeptide and cholecystokinin-8 at the isolated perfused rat pancreas
}

\author{
Hans-Christoph Fehmann ${ }^{1}$, Rüdiger Göke ${ }^{1}$, Burkhard Göke ${ }^{2}$, Rolf Bächle ${ }^{1}$, \\ Birte Wagner ${ }^{1}$ and Rudolf Arnold ${ }^{1}$ \\ ' Department of Internal Medicine, Philipps-University Marburg, Marburg (F.R.G.) \\ and ${ }^{2}$ Department of Physiology, University of Michigan, Ann Arbor, MI (U.S.A.)
}

(Received 29 August 1990)

Key words: Insulin secretior: Priming; GLP-1 (7-36) amide; GIP; Cholecystokinin-8; Rat pancreas

The priming effect of glucagon-like peptide-1 (7-36) amide (GLP-1 (7-36) amide), glucose-dependent insulin-releasing polypeptide (GIP) and cholisystokinin-8 (CCK-8) on glucose-induced insulin secretion from rat pancreas was investigated. The isolated pancreas was perfused in vitro with Krebs-Ringer bicarbonate buffer containing $2.8 \mathrm{mmol} / \mathrm{I}$ glucose. After 10 min this medium was supplemented with GLP-1 (7-36) amide, GIP or CCK-8 (10, 100, 1000 pmol/l) for 10 min. After an additional 10 min period with $2.8 \mathrm{mmol} / \mathrm{l}$ glucose alone, insulin secretion was stimulated with buffer containing $10 \mathrm{mmol} / \mathrm{I}$ glucose for $44 \mathrm{~min}$. In control experiments the typical biphasic insulin response to $10 \mathrm{mmol} / \mathrm{l}$ glucose occurred. Pretreatment of the pancreas with GIP augmented insulin secretion: $10 \mathrm{pmol} / \mathrm{I}$ GIP enhanced only the first phase of the secretory response to $10 \mathrm{mmol} / 1$ glucose; 100 and $1000 \mathrm{pmol} / 1$ GIP stimulated both phases of hormone secretion. After exposure to CCK-8, enhanced insulin release during the first (at 10 and 1000 pmol / CCK-8) and the second phase (at $1000 \mathrm{pmol} / \mathrm{l}$ ) was observed. Priming with $100 \mathrm{pmol} / \mathrm{l} \mathrm{GLP-1}$ (7-36) amide significantly amplified the first and $1000 \mathrm{pmol} / 1$ GLP-1 (7-36) amide both secretion periods. 10 pmol / GLP-1 (7-36) amide had no significant effect. All three peptide hormones influenced the first, quickly arising secretory response more than the second phase. Priming with forskolin $(30 \mathrm{mM})$ enhanced the secretory response to $10 \mathrm{mM}$ glucose plus $0.5 \mathrm{nM}$ GLF-1 (7-36) amide 4-fold. With a glucose-responsive B-cell line (HIT cells), we investigated the hypothesis that the priming effect of GLP-1 (7-30) amide is mediated by the adenylate cyclase system. Priming with either IBMX (0.1 mM) or forskolin $(2.5 \mu \mathrm{M})$ enhanced the insulin release after a consecutive glucose stimulation (5 mM). This effect was pronounced when GLP-1 (7-36) amide (100 pM) was added during glucose stimulation. Priming capacities of intestinal peptide hormones may be involved in the regulation of postprandial insulin release. The incretin action of these hormones can probably, at least in part, be explained by these effects. The priming effect of GLP-1 (7-36) amide is most likely mediated by the adenylate cyclase system.

\section{Introduction}

Insulin secretion from pancreatic beta cells is regulated by metabolic substrates, neurotransmitters and

\footnotetext{
Abbreviations: GLP-1(7-36)amide, glucagon-like peptide-1 (736)amide; GIP, glucose-dependent insulin-releasing polypeptide; CCK-8, cholecystokinin; IBMX, 3-isobutylmethylxanthire.
}

Correspondence (present address): H.C. Fehmann, Laboratory of Molecular Endocrinology, Wellman Building 3, Massachusetts General Hospital, Harvard Medical School, Boston, MA 02114, U.S.A. gastrointestinal hormones. Glucose represents the most powerful stimulator of insulin release [1,2].

It is well established that prior exposure to glucose sensitizes the endocrine pancreas to a subsequent glucose stimulus [3-7]. This 'memory' for a previous glucose stimulation was shown to be both time and dosedependently. It was observed in several species, including man [3-10], and there is no evidence that the islet memory described for glucose is due to the release of intestinal peptides and subsequent effects on the beta cell.

Accumulating evidence suggests that several intestinal hormones are involved in the entero-insulinar axis 
$[1,2]$. The insulinotropic action of glucose-dependent insulin-releasing polypeptide (GIP) is known [11] and in recent studies glucagon-like peptide-1 (7-36) amide (GLP-1 (7-36) amide), a product of the posttranslatonal processing of proglucagon, was suggested as an even more effective incretin candidate [12-18]. It fulfills the classic conditions that allow identification as incretin hormone: it is released from the gut by nutrients, especially carbohydrates [14], and it stimulates insulin secretion in the presence of elevated blood glucose levels [12-18].

In recent reports, Zawalich et al. [20] described a sensitizing effect of high concentrations of CCK on isolated islets, speculating that this action may play a role in a postulated incretin activity of CCK. This concept was supported by recent data demonstrating a change of the beta-cell responsiveness during systemic infusion of CCK [21]. In addition, such a priming action on pancreatic beta-cells was shown for carbachol $[22,23]$. In the case of CCK-priming, an enhanced turnover of membrane phosphoinositides is thought to be responsible for the change in beta-cell sensitivity to a subsequent glucose stimulation [20].

The present study was performed to explore the possible sensitizing effect of the most important incretin factors, GIP, GLP-1 (7-36) amide and CCK on the glucose-induced insulin secretion from perfused rat pancrea s. In addition, experiments with forskolin and IBMX using the perfused rat pancreas and a glucose-responsive beta-cell line (HIT-T-15) were performed to study the mechansims involved in GLP-1 priming.

\section{Materials and Methods}

Materials. Synthetic glucagon-like peptide-1 (7-36) amide, CCK-8 (sulphated) and GIP were purchased from Peninsula (St. Helens, Merseyside, U.K.). Bovine serum albumin (fraction V) was from Serva (Heidelberg, F.R.G.), aprotinin (Trasylol) from Bayer (Leverkusen, F.R.G.), IBMX and forskolin from Sigma (Muischen, F.R.G.). All other chemicals used were analytical grade and were purchased from Merck (Darmstadt, F.R.G.).

Animals. Male albino Wistar rats (180-240 g), kept in a light- and temperature-controlled room, were fed a standard diet (Altromin, Lage, F.R.G.) and had access to water ad libitum.

Tissue culture. HIT-T-15 cells (obtained at passage 59 from American Type Culture Collection, Rockville, MD, U.S.A.) were grown in Ham's F12 K medium (87.5\% $\mathrm{v} / \mathrm{v})$ supplemented with fetal bovine serum $(2.5 \% \mathrm{v} / \mathrm{v})$, dialyzed horse serum $(10 \% \mathrm{v} / \mathrm{v}), 100 \mathrm{U} / \mathrm{ml}$ penicillin and $10 \mu \mathrm{g} / \mathrm{ml}$ streptomycin (all from Gibco, Eggenstein, F.R.G.) in an $95 \% \mathrm{O}_{2} / 5 \% \mathrm{CO}_{2}$ humidified atmosphere at $37^{\circ} \mathrm{C}$. Cells from passages 63-68 were used.
Perfusion experiments. Rats were anesthetized by an intraperitoneal injection of pentobarbitone sodium (45 $\mathrm{mg} / \mathrm{kg}$ body weight). The pancreas, spleen, stomach and proximal part of the duodenum were perfused through cannulated abdominal aorta and coeliac axis as described before [24]. The entire preparation was removed from the cadaver and placed into a perfusion chamber $\left(37^{\circ} \mathrm{C}\right)$ The perfusion media consisted of a Krebs-Ringer bicarbonate buffer (pH 7.40 when gassed with $95 \% \mathrm{O}_{2}$ and $5 \% \mathrm{CO}_{2}$ ) which contained sodium 143 $\mathrm{mmol} / \mathrm{l}$, potassium $5.9 \mathrm{mmol} / 1$, calcium $2.5 \mathrm{mmol} / \mathrm{l}$, magnesium $1.18 \mathrm{mmol} / 1$, phosphate $1.2 \mathrm{mmol} / 1$, sulfate $1.2 \mathrm{mmol} / \mathrm{l}$, carbonate $25 \mathrm{mmol} / \mathrm{l}$, chloride $127 \mathrm{mmol} / \mathrm{l}$, bicarbonate $25 \mathrm{mmol} / 1$ and $0.2 \%$ bovine serum albumin. Venous effluent was collected on aprotinin (1000 $\mathrm{U} / \mathrm{vial}$ ) in intervals by a canula inserted into the portal vein. The perfusion pumps were adjusted to generate a constant flow rate of $5 \mathrm{ml} / \mathrm{min}$. One perfusion experiment lasted for $74 \mathrm{~min}$.

\section{Experimenicul protocol}

Perfusion experiments (Fig. I). After a basal period at $2.8 \mathrm{mmol} / 1$ glucose for equilibration $(10 \mathrm{~min}, \mathrm{I})$ the pancreas was perfused with medium containing 2.8 mmol/1 glucose plus the peptide hormones for $10 \mathrm{~min}$ (control experiments without peptides, II) and then 10 min with buffer at basal conditions $(2.8 \mathrm{mmol} / 1$ glucose, III). Finally, insulin secretion was stimulated with $10 \mathrm{mamol} / 1$ glucose for $44 \mathrm{~min}$ (0-8 min, IV; 9-44 min, V).

Static incubation experimenis. After trypsinization about $10^{6}$ cells (quantitated by a modified Neubauerhemocytometer) were incubated for $60 \mathrm{~min}$ in Eppendorf tubes in $1 \mathrm{ml}$ Krebs-Ringer bicarbonate buffer (as described above) supplemented with $0.2 \%$ bovine serum albumin in the absence of glucose. Then the medium was changed to buffer containing IBMX $(0.1 \mathrm{mmol} / \mathrm{l})$, forskolin $(2.5 \mu \mathrm{M})$ or GLP-1 (7-36) amide (100 pmol/l). After this priming period $(10 \mathrm{~min})$, cells were maintained for $10 \mathrm{~min}$ in Krebs-Ringer bicarbonate buffer. Subsequently insulin secretion was stimulated for $\mathbf{3 0}$ min with glucose, GLP-1 (7-36) amide and IBMX as described in Table IV. Insulin was determined in the entire supernatant after concentration using a vacuum centrifuge. Each medium change and an additional washing step were performed by mild centrifugation (1200 rpm, $2 \mathrm{~min}$ ) and aspiration of the supernatant. IBMX and forskolin were dissolved in ethanol, resulting in a final concentration of $0.1 \%(v / v)$.

Analytical determinations. Insulin was measured by radioimmunoassay [25]. The standard was a mixture of rat insulin I and II (Novo, Mainz, F.R.G.; perfusion experiments) and pork insulin (Sigma, München, F.R.G.; HIT cell studies). The sensitivity of the assay was $0.25 \mathrm{ng} / \mathrm{ml}$, the interassay variance $2.6 \%$, and the intraassay variance $6.8 \%$. 


\section{EXPERIMENTAL PROTOCOL}

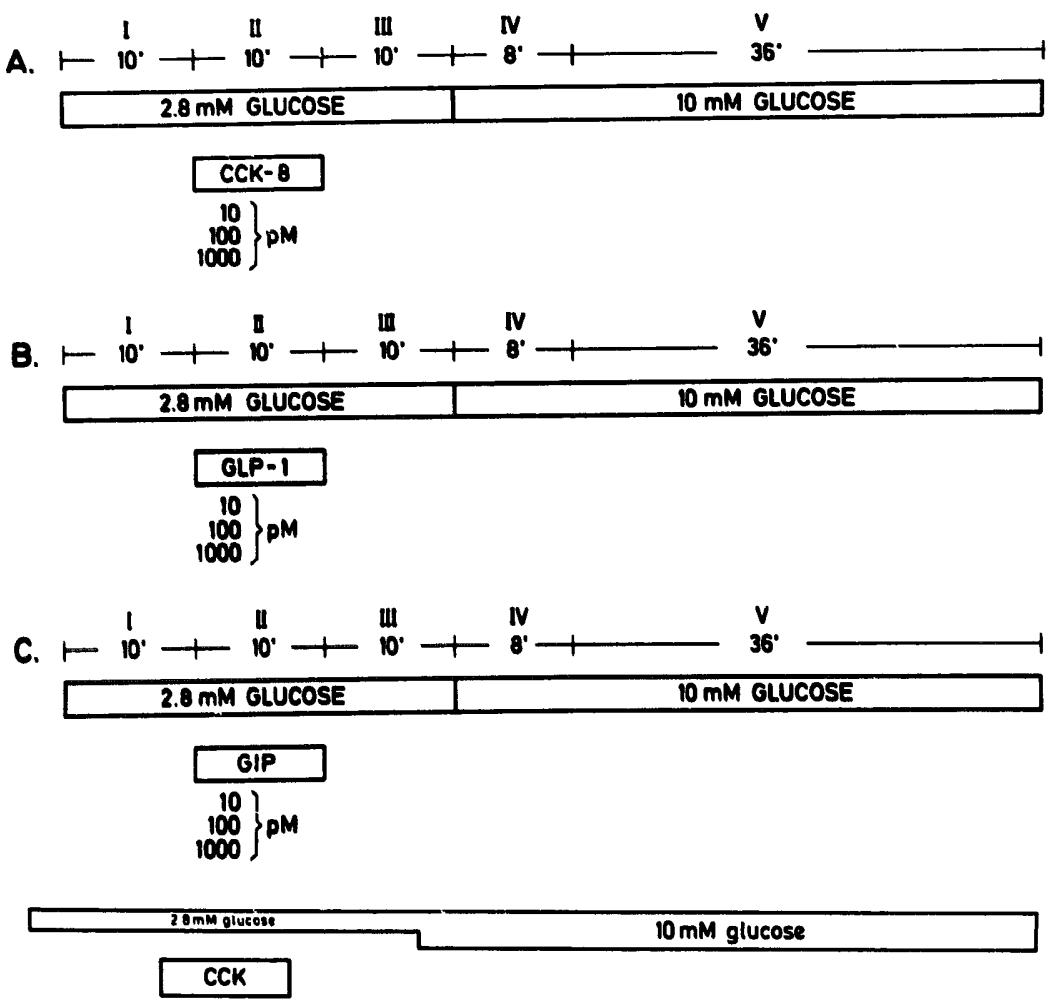

Fig. 1. Experimental protocols. After an equilibration period at basal conditions ( $2.8 \mathrm{mmol} / \mathrm{l}$ glucose, I) pancreata were perfused with medium containing $2.8 \mathrm{mmol} / 1$ glucose plus the peptides (control experiments without hormones; II) and then again with basal glucose (III). Subsequently, insulin release was stimulated by $10 \mathrm{mmol} / \mathrm{l}$ glucose. Insulin release was determined as secretion rates of the first (ng insulin/0-8 min; IV) and the second phase ( $\mathrm{ng}$ insulin/9-44 $\mathrm{min} ; \mathrm{V}$ ) of the biphasic insulin secretion pattern from the isolated perfused rat pancreas. Integrated secretion values were also determined for phases I-III.

Statistics. Insulin secretion from the isolated perfused rat pancreas is expressed as $\mathrm{ng}$ insulin/min (Figs. 2-4) and as integrated hormone release during phases I-V (I-III: $\mathrm{ng}$ insulin/10 $\mathrm{min}$, IV: $\mathrm{ng}$ insulin/8 $\mathrm{min}, \mathrm{V}: \mathrm{ng}$ insulin] $44 \mathrm{~min}$; tables I-III). Insulin secretion from static incubated HIT-T-15 cells was calculated as insulin release/30 min per $10^{6}$ cells; Table IV). Data are given as mean \pm S.E.M. of $(n)$ determinations. Statistical analysis was performed by the $U$-test (perfusion experiments) and Student's $t$-test for unpaired data (HIT cell studies). Statistical significance was set at the 5\% level.

\section{Results}

\section{Pancreas perfusions}

After perfusion of pancreata with medium containing $10 \mathrm{mmol} / 1$ glucose, the typical biphasic insulin response occurred (phase 1, corresponding to IV, and phase 2 to $V$ in Fig: 1) with a 6-8-fold higher hormone release above basal values (Figs. 2-4).

Exposure of the pancreas to CCK-8 (10, 100, 1000 pmol/1) for $10 \mathrm{~min}$ evoked an enhanced insulin secretory response to $10 \mathrm{mmol} / \mathrm{l}$ glucose (Fig. 2, Table I).
Even at a concentration of $10 \mathrm{pmol} / 1 \mathrm{CCK}-8$ augmented significantly the first, quickly arising, insulin secretory response $(145 \% ; P<0.05)$. The second phase was enhanced significantly by $1 \mathrm{nmol} / \mathrm{l}$ CCK-8 (166\%; $P<0.05$; Fig. 2, Table I).

\section{TABLE I}

Effect of priming with CCK $8(10,100,100$ pmol/l) on integrated glucose-induced $(10 \mathrm{mmol} / \mathrm{l})$ insulin secretion from the isolated perfused rat pancreas.

Phases I-V, see Experimental protocol. I: nż insulin/10 min, II: ng insulin/10 $\mathrm{min}$, III: $\mathrm{ng}$ insulin/10 $\mathrm{min}$; IV: $\mathrm{ng}$ insulin/8 $\mathrm{min}, \mathrm{V}: \mathrm{ng}$ insulin/44 min.

\begin{tabular}{llllll}
\hline $\begin{array}{l}\text { CCK-8 } \\
\text { (pmol/l) }\end{array}$ & -5 & \multicolumn{1}{l}{10} & 100 & 1000 \\
$n$ & & 6 & 7 & 7 \\
\hline I & & & & \\
II & $8.9 \pm 1.0$ & $12.7 \pm 3.2$ & $14.4 \pm 3.2$ & $15.4 \pm 1.1$ \\
III & $10.2 \pm 2.1$ & $16.5 \pm 1.7$ & $15.0 \pm 2.2$ & $5.9 \pm 2.3$ \\
IV & $29.1 \pm 3.0$ & $42.2 \pm 7.3 *$ & $3.8 \pm 1.3$ & $10.9 \pm 1.7$ \\
& $100 \%$ & $145 \%$ & $119 \%$ & $219 \%$ \\
V & $205.9 \pm 31.3$ & $236.1 \pm 45.7$ & $224.7 \pm 53.3$ & $311.9 \pm 59.3 *$ \\
& $100 \%$ & $115 \%$ & $109 \%$ & $166 \%$ \\
\hline
\end{tabular}

$* P<0.05$. 

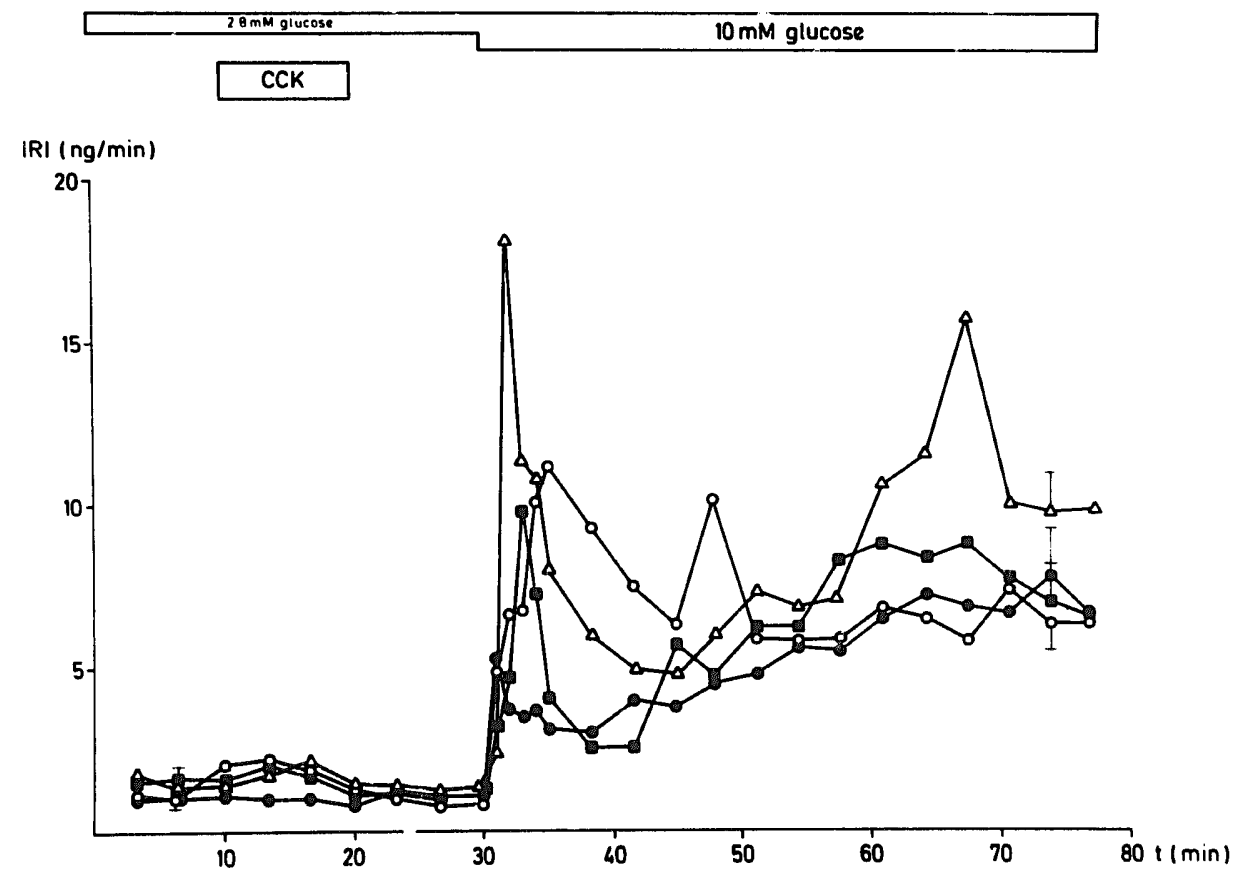

Fig. 2. Effect of priming with CCK-8 $(10,100,1000 \mathrm{pmol} / \mathrm{l})$ on glucose-induced insulin secretion from the isolated perfused rat pancreas. Deuiled data of these experiments are shown in Table I. Control, 1 CCK-8 (pmol/l): 10, 0; 100, 䁅; 1000, $\Delta$.

In a second group of experiments the priming capacity of GLP-1 (7-36) amide on glucose stimulated (10 $\mathrm{mmol} / \mathrm{l})$ insulin secretion was studied. The results are shown in Fig. 3 and Table II. GLP-1 (7-36) amide induced a concentration-dependent (10 pmol/1: 126\%, n.s.; 100 pmol/1: 297\%, $P<0.05$ : 1000 pmol/1: 484\%, $P<0.05$ ) augmentation of insulin secretion during the first phase. The second period was significantly en- hanced by $1000 \mathrm{pmol} / 1$ GLP-1 (7-36) amide (145\%, $P<0.05)$, but not by 100 or 10 pmol/1 GLP-1 (107\% and $117 \%$; respectively).

Since GIP represents another important incretin candidate, we investigated the possible sensitizing activity of GIP on glucose-induced insulin secretion. After priming with all three GIP concentrations we found a significantly higher insulin release during the first secre-

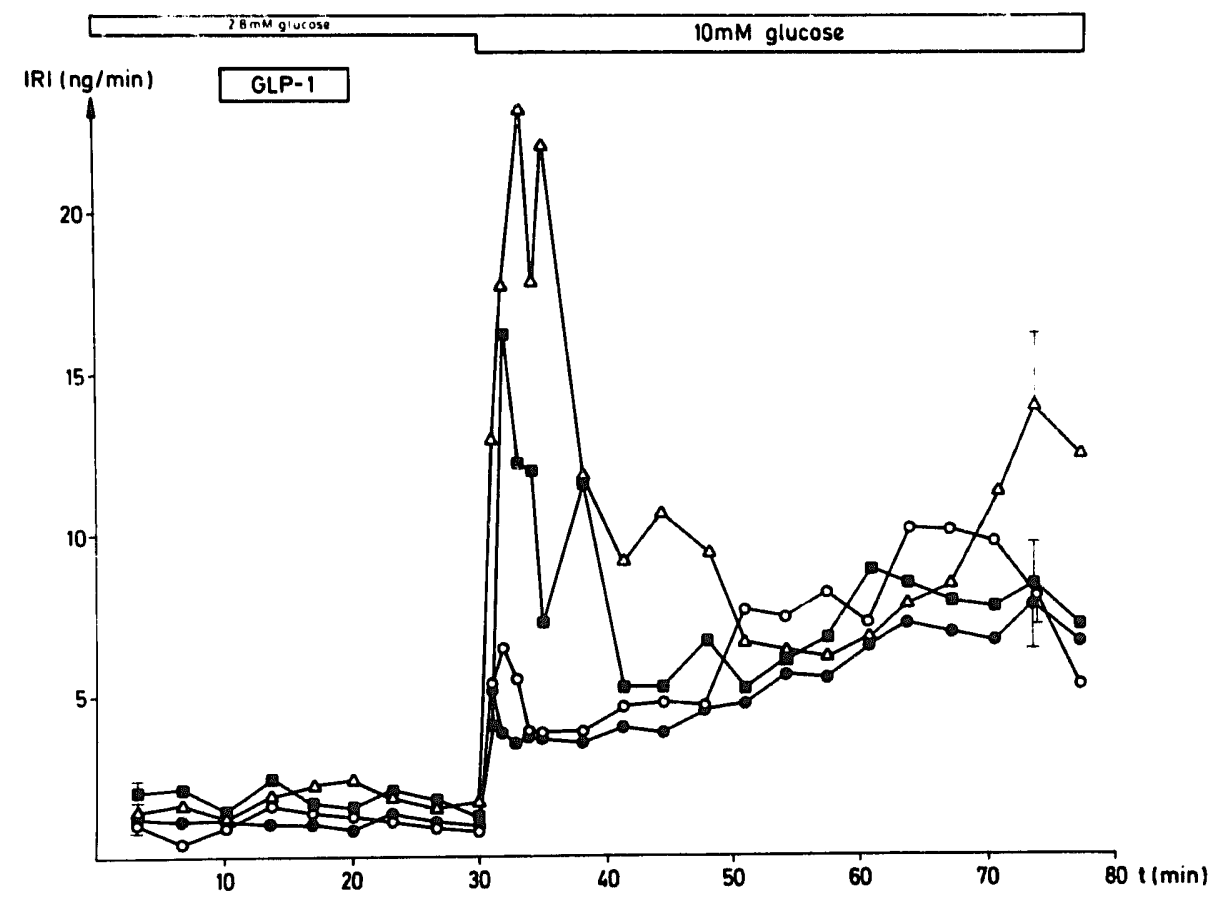

Fig. 3. Effect of priming with GLP-1 (7-36) amide $(10,100,1000 \mathrm{pmol} / 1)$ on glucose-induced insulin secretion from the isolated perfused rat pancreas. Detailed data of these experiments are shown in Table II. Control, ๑. GLP-1 (7-36) amide (pmol/1): 10, $0 ; 100$, , $1000, \Delta$. 


\section{TABLE II}

Effect of priming with GLP-1 (7-36) amide on integrated glucose-induced $(10 \mathrm{mmol} / \mathrm{l})$ insulin secretion from the isolated perfused rat pancreas.

Phases I-V, see Experimental protocol. I: ng insulin/10 min, II: ng insulin/ $10 \mathrm{~min}$, III: $\mathrm{ng}$ insulin/10 $\mathrm{min}$; IV: $\mathrm{ng}$ insulin/8 $\mathrm{min}, \mathrm{V}: \mathrm{ng}$ insulin/44 min.

\begin{tabular}{lllll}
\hline GLP-1 & - & 10 & 100 & 1000 \\
(7-36) & 20 & 6 & 5 & 5 \\
amide & & & & \\
(pmol & & & & \\
I0 $n$ & & & & \\
\hline I & $12.7 \pm 1.0$ & $8.7 \pm 1.1$ & $16.7 \pm 2.0$ & $13.1 \pm 2.0$ \\
II & $8.9 \pm 1.1$ & $12.6 \pm 0.6$ & $15.1 \pm 3.1$ & $16.2 \pm 2.1$ \\
III & $10.2 \pm 2.1$ & $8.5 \pm 0.4$ & $16.6 \pm 2.2$ & $17.5 \pm 2.4$ \\
IV & $29.1 \pm 3.0$ & $36.1 \pm 8.1$ & $86.5 \pm 14.2 *$ & $140.9 \pm 136.0 *$ \\
& $100 \%$ & $126 \%$ & $297 \%$ & $484 \%$ \\
V & $205.9 \pm 31.3$ & $241.8 \pm 61.7$ & $220.2 \pm 27.4$ & $299.0 \pm 35.6 *$ \\
& $100 \%$ & $117 \%$ & $107 \%$ & $145 \%$ \\
\hline
\end{tabular}

$P<0.05$.

tion phase (10 pmol/l: 192\%; $P<0.05 ; 100 \mathrm{pmol} / \mathrm{l}$ : 410\%, $P<0.05 ; 1000 \mathrm{pmol} / \mathrm{l}: 436 \%, P<0.05)$. The second period was positively modulated by $1000 \mathrm{pmol} / 1$ GIP (244\%, $P<0.05)$. However, 10 and 100 pmol/1 GIP had no significant effect. For detailed data see Fig. 4 and Table III.

At identical concentrations of hormones, GIP was more potent to auginent an insulin response to a subsequent glucose stimulation than GLP-1 (7-36) amide. 10 pmol/1 GIP, but not 10 pmol/1 GLP-1 (7-36) amide enhanced the first secretion period and $100 \mathrm{pmol} / \mathrm{l}$

\section{TABLE III}

Effect of GIP (10,100, $1000 \mathrm{pmol} / \mathrm{l})$ on glucose-induced $(10 \mathrm{mmol} / \mathrm{l})$ insulin secretion from the isolated perfused rat pancreas

Phases I-V, see Experimental protocol. I: ng insulin/10 min, II: ng insulin/10 min, III: $\mathrm{ng}$ insulin/10 $\mathrm{min}$, IV: $\mathrm{ng}$ insulin/8 $\mathrm{min}, \mathrm{V}: \mathrm{ng}$ insulin/44 $\mathrm{min}$.

\begin{tabular}{lllll}
\hline $\begin{array}{l}\text { GIP } \\
\text { (pmol/1) }\end{array}$ & - & 10 & 100 & \multicolumn{1}{l}{1000} \\
$n$ & & 6 & \multicolumn{1}{l}{6} & \multicolumn{1}{l}{6} \\
\hline I & $12.7 \pm 1.0$ & $16.3 \pm 5.6$ & $6.4 \pm 0.8$ & $9.8 \pm 2.0$ \\
II & $8.9 \pm 1.1$ & $22.9 \pm 3.3$ & $13.8 \pm 1.1$ & $19.9 \pm 4.6$ \\
III & $10.2 \pm 2.1$ & $13.0 \pm 1.2$ & $8.6 \pm 1.1$ & $13.0 \pm 1.3$ \\
IV & $29.1 \pm 3.0$ & $56.0 \pm 9.8 *$ & $119.2 \pm 7.5$ & $126.8 \pm 29.0 *$ \\
& $100 \%$ & $192 \%$ & $410 \%$ & $436 \%$ \\
V & $205.9 \pm 31.3$ & $281.7 \pm 35.2$ & $348.1 \pm 45.5 *$ & $504.2 \pm 96.8 *$ \\
& $100 \%$ & $137 \%$ & $169 \%$ & $244 \%$ \\
\hline
\end{tabular}

$P<0.05$.

GIP, but not 100 pmol/1 GLP-1 (7-36) amide, amplified the second phase.

In comparison to GLP-1 (7-36) amide and GIP priming with equimolar concentrations of CCK-8 exerted only moderate effects on glucose stimulated insulin release. When the effect of CCK-8 was studied insulin secretion values of approx. 50\%, compared to corresponding experiments with GLP-1 (7-36) amide and GIP, were achieved.

Priming with all three peptide hormones influenced both phases of glucose-induced insulin secretion in a different manner. Low concentrations of hormone induced an augmented hormone secretion of the first, but

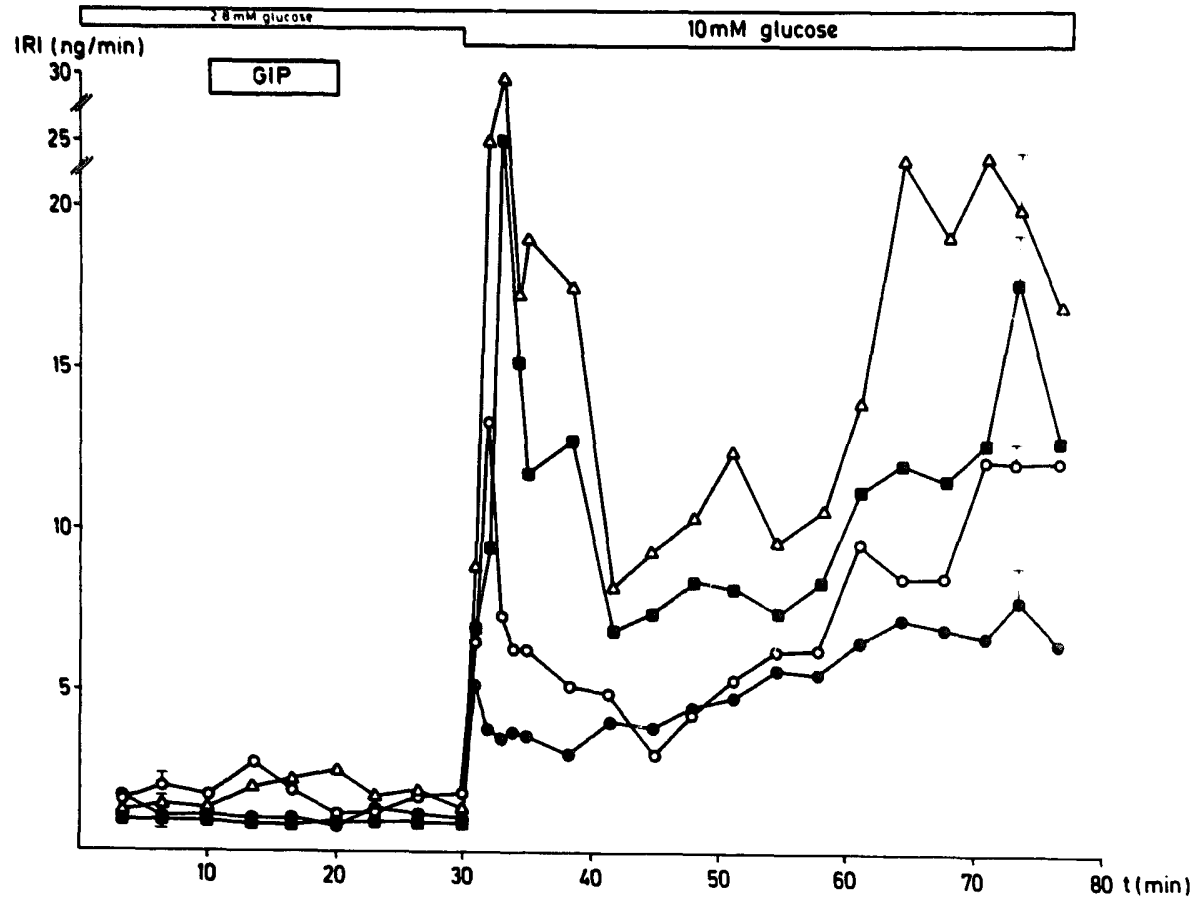

Fig. 4. Effect of priming with GIP (10, 100,1000 pmol/l) on glucose-induced insulin secretion from the isolated perfused rat pancreas. Detailed data of these experiments are shown in Table III. Control, $\bullet$. GIP (pmol/1): 10, $\odot ; 100, \pm ; 1000, \Delta$. 
not the second, phase. When high hormone concentrations were utilized $(1000 \mathrm{pmol} / \mathrm{l})$ the quick, first insulin response to glucose was more enhanced than the response observed in the second, later phase (GIP: $436 \%$ vs. $244 \%$; GLP-1 (7-36) amide: $484 \%$ vs. $145 \%$; CCK-8: $229 \%$ vs. $166 \%$; Table I-III).

None of the tested peptides influenced the basal ( 2.8 mmol/1 glucose) insulin secretion (Figs. 2-4, Tables I-III).

Perfusion of pancreata with forskolin $(30 \mathrm{mM})$ in the presence of $2.8 \mathrm{mM}$ glucose doubled basal insulin release $(56.9 \pm 18.5$ vs. $28.4 \pm 7.8 \mathrm{ng}$ insulin/10 $\mathrm{min})$ and after a $10 \mathrm{~min}$ washout period the secretory response to $10 \mathrm{mM}$ glucose plus $0.5 \mathrm{nM}$ GLP-1 was markedly enhanced compared to the respective controls (no forskolin pretreatment: first phase: $418.3 \pm 71.4$ vs. 118.8 $\pm 25.4 \mathrm{ng}$ insulin $/ 8 \mathrm{~min}$; second phase: $2584.9 \pm 510.8$ vs. $485.8 \pm 53.9 \mathrm{ng}$ insulin $/ 44 \mathrm{~min}$ ).

\section{HIT cell studies (Table IV)}

Priming of HIT cells by IBMX $(0.1 \mathrm{mM})$, forskolin $(2.5 \mu \mathrm{M})$, or GLP-1 (7-36) amide (100 pM) resulted in a modest stimulation of insulin release when glucose concentration was raised to $5 \mathrm{mM}$. This stimulatory effect was significantly increased when, after IBMX or for-

\section{TABLE IV}

Effect of priming with IBMX, forskolin and GLP-1 (7-36) amide on insulin release from HIT cells.

The cells were incubated for $10 \mathrm{~min}$ in buffer (without glucose) supplemented with $100 \mathrm{pM}$ GLP-1 (7-36) amide, $0.1 \mathrm{mM}$ IBMX or $2.5 \mu \mathrm{M}$ forskolin. After a $10 \mathrm{~min}$ washout period, insulin secretion Wus stimulated for $30 \mathrm{~min}$ with glucose, GLP-1 (7-36) amide and IBMX as indicated.

\begin{tabular}{|c|c|c|c|}
\hline Priming period & Stimulation period & $\begin{array}{l}\text { Insulin release } \\
\left(\mathrm{ng} / 10^{6} \text { cells } /\right. \\
30 \mathrm{~min})\end{array}$ & $n$ \\
\hline $\begin{array}{l}- \\
- \\
-\end{array}$ & $\begin{array}{l}5 \mathrm{mM} \text { glucose } \\
10 \mathrm{mM} \text { glucose } \\
5 \mathrm{mM} \text { glucose } \\
+0.1 \mathrm{mM} \text { IBMX } \\
5 \mathrm{mM} \text { glucose }+ \\
100 \text { pM GLP-1 } \\
5 \mathrm{mM} \text { glucose }+ \\
2.5 \mu \mathrm{M} \text { forskolin }\end{array}$ & $\begin{array}{l}0.06 \pm 0.006 \\
0.08 \pm 0.015 \\
0.60 \pm 0.021 * \\
0.08 \pm 0.018 \\
0.42 \pm 0.012 *\end{array}$ & $\begin{array}{l}9 \\
4\end{array}$ \\
\hline $\begin{array}{l}100 \text { pM GLP-1 } \\
100 \text { pM GLP-1 }\end{array}$ & $\begin{array}{l}5 \mathrm{mM} \text { glucose } \\
5 \mathrm{mM} \text { glucose }+ \\
0.1 \mathrm{mM} \text { IBMX }\end{array}$ & $\begin{array}{l}0.17 \pm 0.014 * \\
0.67 \pm 0.070 *\end{array}$ & 6 \\
\hline $\begin{array}{l}0.1 \mathrm{mM} \text { IBMX } \\
0.1 \mathrm{mM} \text { IBMX }\end{array}$ & $\begin{array}{l}5 \mathrm{mM} \text { glucose } \\
5 \mathrm{mM} \text { glucose }+ \\
100 \text { pM GLP-1 }\end{array}$ & $\begin{array}{l}0.18 \pm 0.042 * \\
0.25 \pm 0.023 *\end{array}$ & 6 \\
\hline $\begin{array}{l}2.5 \mu \mathrm{M} \text { forskolin } \\
2.5 \mu \mathrm{M} \text { forskolin }\end{array}$ & $\begin{array}{l}5 \mathrm{mM} \text { glucose } \\
5 \mathrm{mM} \text { glucose + } \\
100 \text { pM GLP-1 }\end{array}$ & $\begin{array}{l}0.12 \pm 0.004 * \\
0.57 \pm 0.013 *\end{array}$ & 6 \\
\hline
\end{tabular}

* $P<0.05$ compared to control experiments (no priming, $5 \mathrm{mM}$ glucose); GLP-1 = GLP-1 (7-36) amide. skolin priming, GLP-1 (7-36) amide was added at a concentration of $100 \mathrm{pM}$. At $100 \mathrm{pM}$, GLP-1 (7-36) amide exerted no significant stimulatory effect when the cells were studied without prior priming. When the cells were pretreated with GLP-1 (7-36) amide (100 pM), addition of IBMX $(0.1 \mathrm{mM})$ potentiated the glucose-induced insulin release. However, this effect was not different compared with a sole IBMX-stimulation without prior priming.

\section{Discussion}

The acute and glucose-dependent insulinotropic action of physiological concentrations of GIP and GLP-1 (7-36) amide have been previously reported [11-18]. In rats CCK seems to stimulate the glucose-induced insulin secretion only in high, supraphysiological concentrations $[17,26,27]$ and in man endogenous and exogenous CCK had no insulinotropic activity $[28,29]$. On the other hand, physiological CCK levels potentiate the GIP-(30) and GLP-1 (7-36) amide-induced insulin secretion [17]. Therefore, the role of CCK in the enteroinsulinar axis is not exactly defined. Data of the present study now suggest an additional indirect action of these incretin hormones at the pancreatic beta cell: short time exposure of the pancreas at nearly physiologic postprandial concentrations to one of these peptides increased the respective insulin response to a subsequent glucose stimulation. Comparable to studies with CCK-8 performed by Zawalich et al. $[19,20]$, we observed a differential influence of such priming on biphasic insulin secretion pattern: all three peptide hormones enhanced the first rapid response to glucose stimulation more than the second phase (Figs. 2-4, Table I-III). This is of particular interest, since the first phase is thought to be more important in regulation of insulin efficacy than the second phase [31].

In the case of CCK-8 and GIP it was possible to demonstrate a priming effect of even $10 \mathrm{pmol} / 1$ of each peptide at the isolated perfused rat pancreas (Figs. 2, 4, Table I, III). Using isolated islets, Zawalich et al. [19] found no priming effect of CCK-8 in concentrations lower than $10 \mathrm{nmol} / 1 \mathrm{CCK}-8$. This discrepancy can be explained by the use of different models (perfused pancreas vs. collagenase isolated islets). It is known that islets isolated with collagenase method are more insensitive to various secretagogues than the isolated perfused gland [32].

Interestingly, we observed differences in the priming capacity between the three tested incretin hormones: 1 nmol/1 GIP and GLP-1 (7-36) amide induced a 4-5-fold higher insulin secretion rate of the first phase and 1 nmol/1 CCK-8 only doubled the quick-arising secretion period.

On the other hand, $10 \mathrm{pmol} / 1 \mathrm{CCK}-8$ and GIP, but not 10 pmol/1 GLP-1 (7-36) amide, sensitized the beta 
cells to the subsequent glucose stimulus. Therefore, it seems possible that CCK sensitizes insulin secretion in lower concentrations than GLP-1 (7-36) amide, but GLP-1 (7-36) amide and GIP are able to induce a stronger augmentation of glucose-induced insulin secretion after sensitizing. Since nutrients administered by the gastrointestinal route are more potent in enhancing insulin release than the same substances given directly intravascularly (the 'incretin effect'), these phenomena could represent very sensitive and elegant mechanisms in regulation of the adequate postprandial insulin response to prevent hypo- and hyperglycemia.

Although the intracellular mechanism of glucose priming remains to be defined, some evidence to explain the effects of gastrointestinal hormones exists which allows the construction of a working hypothesis. In the case of CCK, Zawalich et al. [20] suggested that the turnover of membrane phosphoinositides induced by CCK is largely responsible for the heightened status of secretory responsiveness to various stimuli of insulin release. Previously, we have shown that the GLP-1 (7-36) amide-stimulated, glucose-induced insulin release is strongly potentiated by CCK [17]. Since the signal transmission after binding of GLP-1 (7-36) amide is adenylate-cyclase-linked $[15,33,34]$, we have explained the CCK potentiation of the GLP-1 (7-36) amide effect by a synergistic interaction of the different second messenger systems as was suggested previously for the interaction of CCK and GIP [30]. Furthermore, an additive and not potentiated synergistic effect on the glucose-induced insulin secretion was reported when GLP-1 (7-36) amide and GIP were combined [18]. Since both hormones act via the adenylate cyclase system, the combination of both resulted in an additive effect on insulin release when submaximal, effective concentrations were used. From these results we speculate that the priming effect of GLP-1 (7-36) amide on the glucose-induced insulin release is mediated by the adenylate cyclase system. Previous experimental evidence exists to support our hypothesis.

It was earlier demonstrated, that IBMX exerts a priming effect upon rat pancreatic islets that results in a prompt enhancement of the insulin release in response to a subsequent stimulation [35]. After IBMX, the islets had a 'memory' for this preexposure that lasted at least $30 \mathrm{~min}$ [35]. Our data support these findings. Furthermore, GLP-1 (7-36) amide potentiated the glucose-induced insulin secretion after IBMX or forskolin priming.

Since the GLP-1 (7-36) amide action relies on an activation of the adenylate cyclase system [34], these data argue in favor of an involvement of the adenylate cyclase system during GLP-1 (7-36) amide priming. Whereas IBMX enhances intracellular cAMP levels by an inhibition of the phosphodiesterase, which is responsible for the cAMP degradation, forskolin directly activates the catalytic subunit of adenylate cyclase and thereby increases islet cAMP levels [36]. After forskolin priming the secretory response to glucose plus GLP-1 from HIT cells as well as from the perfused pancreas was much higher compared to the respective controls, which again argues in favour of an involvement of the adenylate cyclase system.

It has been reported that cAMP negatively affects phosphoinositide turnover in different tissues $[38,39]$. If forskolin is added to the incubation medium of islets in the presence of $5.5 \mathrm{mM}$ glucose, an amplified insulin secretory response results which is accompanied by a reduction of inositol phosphate accumulation [40]. Furthermore, GIP has been shown to increase islet cAMP levels and to reduce the stimulatory effect of CCK on PI-hydrolysis, but to amplify insulin secretion [41].

When taken in their entirety, these results suggest that the priming effect of GLP-1 (7-36) amide and probably GIP is mediated by the adenylate cyclase system. Our data are consistent with the concept that a relationship between cAMP levels in the islets and the efficacy of other second messenger systems exists to stimulate insulin secretion.

In conclusion, data of the present study indicate that:

(1) priming with CCK-8, GIP or GLP-1 (7-36) amide sensitizes rat endocrine pancreas to a subsequent glucose stimulus;

(2) this sensitizing effect is more pronounced for the first phase of the biphasic insulin secretion pattern;

(3) low concentrations (10 pmol/l) of CCK-8 and GIP, but not of GLP-1 (7-36) amide induced a priming effect;

(4) at higher concentrations (100 and $1000 \mathrm{pmol} / \mathrm{l})$ priming by GIP and GLP-1 (7-36) amide is more potent than priming by $\mathrm{CCK}-8$;

(5) the priming effects of GLP-1 (7-36) amide and probably GIP seem to be mediated by the adenylate cyclase system.

\section{Acknowledgements}

This work was supported by grants DFG Go 492/1-1, P.E. Kempkes RWH-493-51 (59/2) and the A. Schmidtmann Foundation (Marburg) which is gratefully acknowledged. B.G. is a research fellow of the Deutsche Forschungsgemeinschaft (Heisenberg programme). The authors thank $\mathrm{H}$. Loth for skilful technical assistance.

\section{References}

1 Creutzfeldt, W. (1979) Diabetologial 6, 75-85.

2 Creutzfeldt, W. and Ebert, R. (1985) Diabetologia 28, 565-573.

3 Cerasi, E. (1975) Acta Endocrinol. (Copenh.) 79, 483-501.

4 Efendic, S., Lins, P., and Cerasi, E. (1979) Acta Endocrinol. (Copenh.) 90, 259-271.

5 Nesher, R. and Cerasi, E. (1987) Endocrinology 121, 1017-1024. 
6 Grill, V., Adamson, U., Rundfeldt, M., Andersson, S. and Cerasi, E. (1979) J. Clin. Invest. 64, 700-707.

7 Nesher, R., Praiss, M. and Cerasi, E. (1988) Acta Endocrinol. (Copenh.) 117, 409-415.

8 Grill V. (1981) Am. J. Physiol. 240, E24-E31.

9 Grill, V., Adamson, U. and Cerasi, E. (1978) J. Clin. Invest. 61, $1034-1043$.

10 Grill, V. and Rundfeldt, M. (1979) Endocrinology 105, 980-987.

11 Brown, JC. (1982) Gastric Inhibitory Polypeptide, Springer, Berlin.

12 Mojsov, S., Weir, G. and Habener, J.F. (1987) J. Clin. Invest. 79, 616-619.

13 Weir, G., Mojsov, S., Hendrick, G.K. and Habener, J.F. (1989) Diabetes 38, 338-342.

14 Kreymann, B., Williams, G., Ghatei, M.A. and Bloom, S.R. (1987) Lancet ii, 1300-1304.

15 Gefel, D., Hendrick, G.K., Mojsov, S., Habener, J.F. and Weir, G.C. (1990) Endocrinology 126, 2164-2168.

16 Göke, R., Fehmann, H.C., Richter, G., Trautmann, M.E. and Göke, B. (1989) Pancreas 4, 668-673.

17 Fehmann, H.C., Göke, B., Weber, V., Göke, R., Trautmann, M.E. and Arnold, R. (1990) Pancreas 5, 361-365.

18 Fehınann, H.C., Göke, B., Göke, R., Trautmann, M.E. and Arnold, R. (1989) FEBS Lett. 252, 109-112.

19 Zawalich, W.S. and Diaz, V. (1987) Diabetes 36, 116-122.

20 Zawalich, W.S., Diaz, V.A. and Zawalich, K.C. (1987) Diabetes $36,1420-1424$.

21 Balkan, B., Steffens, A.B., Strubbe, J.H. and Bruggink, J.E. (1990) Diabetes 39, 702-710.

22 Zawalich, W.S., Zawalich, K.C. and Rasmussen H. (1989) Endocrinology 125, 2400-2406.

23 Fehmann, H.C., Göke, R., Göke, B. and Arnold, R. (1990) Z. Gastroenterologie 28, 348-352.

24 Grodsky, G.M., Batts, A.A., Bennett, L.L, Vcella, C., McWilliams, N.B. and Smith DF. (1963) Am. J. Physiol. 205, 638-644.
25 Herbert, V., Lau, K.S., Gottlieb, C.W. and Bleicher, S.J. (1965) J. Clin. Endocrinol. Metabol. 25, 1375-1381.

26 Müller, M.K., Demol, P., Fladrich, G., Goebell, H. and Pederson, R.A. (1983) Digestion 27, 245-251.

27 Okabayashi, Y., Otsuki, M., Ohki, A., Sakamoto, C. and Baba, S. (1983) Endocrinology 113, 2210-2215.

28 Reimers, J., Nauck, M., Creutzfeldt, W., Strietzel, J., Ebert, R., Cantor, P. and Hoffmann, G. (1988) Diabetologia 31, 271-280.

29 Liddle, R.A., Gertz, B.J., Kanayama, S., Beccaria, L., Gettys, T.W., Taylor, I.L., Rushakoff, R.J., Williams, V.C. and Coker, L.D. (1990) J. Clin. Endocrinol. Metabol. 70, 1312-1318.

30 Ahren, B., Hedner, P. and Lundquist, I. (1983) Acta Endocrinol. (Copenh.) 102, 96-102.

31 Steiner, K.F., Mouton, S.M., Boeles, C.R., Williams, P.E. and Cherrington AD. (1982) Disbetes 31, 964-972.

32 Verspohl, E.J., Ammon; H.P.T., Williams, J.A. and Goldfine, I.D. (1986) Diabetes 35, 38-42.

33 Drucker, D., Philippe, J., Mojsov, S., Chick, W.L. and Habener, J.F. (1987) Proc. Natl. Acad. Sci. USA 84, 3434-3438.

34 Göke, R., Trautmann, M.E., Haus, E., Richter, G., Fehmann, H.C., Arnold, R. and Göke, B. (1989) Am. J. Physiol. 257, G397G401.

35 Wiedenkeller, D. and Sharp, G.W.G. (1981) Diabetes 30, 754-756.

36 Wiedenkeller, D. and Sharp, G.W.G. (1983) Endocrinology 113, 2311-2313.

37 Ammon, H.P.T. and Mueller, A.B. (1984) Naunyn-Schmiedeberg's Arch. Pharmacol. 326, 364-367.

38 Lapetina, E.G. and Siegal, F.L. (1983) J. Biol. Chem. 258, 72417244.

39 Woodcock, E.A., Smith, A.l. and White, L.S.B. (1988) Endocrinology 122, 1053-1059.

40 Zawalich, W.S., Diaz, V. ı. and Zawalich, K.C. (1988) Diabetes 37, 1478-1483.

41 Zawalich, W.S. (1988) Metabolism 37, 778-781. 